\title{
An immunocompetent patient with a nonsense mutation in NHEJ1 gene
}

\author{
Hossein Esmaeilzadeh ${ }^{1,2}$, Mohammad Reza Bordbar ${ }^{3}$, Zahra Hojaji ${ }^{2}$, Parham Habibzadeh ${ }^{4,5}$, Dorna Afshinfar ${ }^{4}$, \\ Mohammad Miryounesi ${ }^{6}$ (D) Majid Fardaei ${ }^{7,8}$ and Mohammad Ali Faghihi $i^{4,9^{*}}$
}

\begin{abstract}
Background: DNA double-strand breaks (DSBs) are among the most deleterious types of DNA damage. DSBs are repaired by homologous recombination or non-homologous end-joining (NHEJ). NHEJ, which is central to the process of $\mathrm{V}(\mathrm{D}) \mathrm{J}$ recombination is the principle pathway for DSB repair in higher eukaryotes. Mutations in NHEJ1 gene have been associated with severe combined immunodeficiency.
\end{abstract}

Case presentation: The patient was a 3.5-year-old girl, a product of consanguineous first-degree cousin marriage, who was homozygous for a nonsense mutation in NHEJ1 gene. She had initially presented with failure to thrive, proportional microcephaly as well as autoimmune hemolytic anemia (AlHA), which responded well to treatment with prednisolone. However, the patient was immunocompetent despite having this pathogenic mutation.

Conclusions: Herein, we report on a patient who was clinically immunocompetent despite having a pathogenic mutation in NHEJ1 gene. Our findings provided evidence for the importance of other end-joining auxiliary pathways that would function in maintaining genetic stability. Clinicians should therefore be aware that pathogenic mutations in NHEJ pathway are not necessarily associated with clinical immunodeficiency.

Keywords: Severe combined immunodeficiency, Nonhomologous end-joining factor 1, human, Autoimmune hemolytic Anemia, Genetic disorders, Immunologic deficiency syndromes

\section{Background}

DNA double-strand breaks (DSBs), resulting in loss of considerable chromosomal regions, are among the most deleterious types of DNA damage. With an estimated rate of ten per day, DSBs can either be caused by DNA damaging agents such as reactive oxygen species or could be a part of physiological DNA recombination taking place in the immune system $[1,2]$. $\mathrm{V}(\mathrm{D}) \mathrm{J}$ recombination is a process during which the highly diverse lymphocyte antigen receptors breed. One of the consequences of this process is DSB [3]. If left unrepaired, DSB will induce either apoptosis or cellular dysfunction [4].

DSBs are repaired by homologous recombination or non-homologous end-joining (NHEJ) [5]. Error-prone NHEJ, which is central to the process of $\mathrm{V}(\mathrm{D}) \mathrm{J}$ recombination, is the main pathway of DSB repair system in

\footnotetext{
* Correspondence: MFaghihi@med.miami.edu

${ }^{4}$ Persian BayanGene Research and Training Center, Shiraz, Iran

${ }^{9}$ Center for Therapeutic Innovation, Department of Psychiatry and Behavioral

Sciences, University of Miami Miller School of Medicine, Miami, USA

Full list of author information is available at the end of the article
}

higher eukaryotes $[5,6]$. Considering its major role in the immune system development, deficiency of NHEJ1 gene products manifests with absence of mature $\mathrm{T}$ and $\mathrm{B}$ lymphocytes, also known as "severe combined immunodeficiency" (SCID) [7]. Mutations in the NHEJ1 have been associated with the clinical phenotype of severe combined immunodeficiency with microcephaly, growth retardation, and sensitivity to ionizing radiation (Phenotype MIM \# 611291). The patients reported so far have always presented with clinical manifestations such as failure to thrive (FTT), severe growth retardation, microcephaly, and autoimmune hemolytic anemia (AIHA) [8-10]. Herein, we report on a patient who was clinically immunocompetent despite having a pathogenic mutation in NHEJ1 gene.

\section{Case presentation}

The patient was a 3.5-year-old girl, a product of consanguineous first-degree cousin marriage, who was born at the gestational age of 38 weeks after a normal and uncomplicated pregnancy. She was in good health after delivery with a good APGAR score. Her weight, length

(c) The Author(s). 2019 Open Access This article is distributed under the terms of the Creative Commons Attribution 4.0 International License (http://creativecommons.org/licenses/by/4.0/), which permits unrestricted use, distribution, and reproduction in any medium, provided you give appropriate credit to the original author(s) and the source, provide a link to the Creative Commons license, and indicate if changes were made. The Creative Commons Public Domain Dedication waiver (http://creativecommons.org/publicdomain/zero/1.0/) applies to the data made available in this article, unless otherwise stated. 
and head circumference were $2500 \mathrm{~g}, 45 \mathrm{~cm}$ and $33 \mathrm{~cm}$, respectively. Weight and length were below the 3rd percentile, whereas head circumference was slightly above the 15th percentile according to the national child growth curve. Failure to thrive and proportional microcephaly continued until one year of age but development was good. She presented with jaundice at the age of one year. Laboratory tests showed decreased WBC count $\left(3000 / \mathrm{mm}^{3}\right.$, reference range for age: $\left.5000-15,500 / \mathrm{mm}^{3}\right)$ with $64 \%$ neutrophil and decreased hemoglobin levels $(11 \mathrm{~g} / \mathrm{dL}$, reference range for age: $12-14 \mathrm{~g} / \mathrm{dL})$. Furthermore, lab results revealed an $\mathrm{MCV}$ of $88.7 \mathrm{fL}$, platelet count of 261,000 , ESR of $2 \mathrm{~mm} / \mathrm{h}$, reticulocyte count of $5.1 \%$, a positive direct Coomb's test, negative indirect Coomb's test. Moreover, ACLA, ANA, ds-DNA, C3, C4, ANCA were within normal range. Osmotic fragility test was negative. $\mathrm{Hb}$ electrophoresis showed $\mathrm{Hb}-\mathrm{A} 1$ of $91.8 \%, \mathrm{Hb}-\mathrm{F}$ of $5.7 \%$, and $\mathrm{Hb}-\mathrm{A} 2$ of $2.5 \%$. Viral marker tests revealed negative cytomegalovirus (CMV) PCR and parvovirus antibody. The patient was referred to a hemato-oncologist with a diagnosis of AIHA and was subsequently treated with prednisolone. The patient's parents did not mention any history of hospitalization or outpatient visits due to infectious disorders. Furthermore, according to her flow-cytometry results, low level of CD19+ and the very high level of CD56+ cells were detected. (Table 1). The immunophenotyping test were performed at the age of 2.5 years.

As the patient was a result of a consanguineous marriage, a thorough family history was taken from her parents. Both her parents were in good health. The other sibling was a boy who presented with jaundice and anemia at the age of three months. He then presented with recurrent infections and passed away at the age of three years due to pneumonia. Serum PCR for CMV was positive in the deceased individual. No further clinical and laboratory data were available.

To evaluate the patient for the underlying genetic disorder, whole-exome sequencing was carried out on the DNA extracted from the proband's peripheral blood sample. Whole Exome Sequencing (WES) was performed on Illumina NextSeq500 instrument. The sequencing results were subsequently analyzed using different bioinformatics tools and databases such as BWA aligner, GATK and ANNOVAR. Whole exome sequencing details of coverage and number of reads are provided in Table 2. It was found that the patient had a stop-gain mutation in NHEJ1 gene (NM_024782.2:c.532C > A). Sanger sequencing subsequently confirmed that the patient was homozygous and both parents were heterozygous for the mutation (Fig. 1).

On follow-up, the patient had growth and development retardation with her length/height, head circumference and weight being below the 3rd percentile corrected for the age. Except for axillary lymphadenitis following BCG
Table 1 The results of flow-cytometry and blood count

\begin{tabular}{|c|c|c|}
\hline Laboratory Test & Values & Reference Values \\
\hline CD3+ \% (Absolute cell value) & $40 \%(306)$ & $39-73 \%$ \\
\hline CD16+ \% (Absolute cell value) & $55 \%(420)$ & $8.3-17.5 \%$ \\
\hline CD45+ \% (Absolute cell value) & $88 \%(673)$ & \\
\hline CD11b + (adhesion molecules) & Normal & \\
\hline CD4+ \% (Absolute cell value) & $28 \%(214)$ & $25-50 \%$ \\
\hline CD8+ \% (Absolute cell value) & $8 \%(61)$ & $11-32 \%$ \\
\hline CD19+ \% (Absolute cell value) & $5 \%(38)$ & $17-41 \%$ \\
\hline CD14+ \% (Absolute cell value) & $12 \%(90)$ & $3-6 \%$ \\
\hline CD56+ (NK cells) & 55 & $8.3-17.5$ \\
\hline CD4/CD8 & 3.50 & $0.9-3.7$ \\
\hline CD20+ \% (Absolute cell value) & $5 \%(42)$ & $17-41 \%$ \\
\hline Interferon y receptor & Normal & \\
\hline WBC count & 3100 & $5000-15,500$ \\
\hline Neutrophil \% (Absolute cell value) & $64.5 \%(2000)$ & \\
\hline Lymphocyte \% (Absolute cell value) & $24.7 \%(765)$ & \\
\hline Mix \% (Absolute cell value) & $10.8 \%(335)$ & \\
\hline $\mathrm{Hb}(\mathrm{g} / \mathrm{dL})$ & 11.1 & $12-14$ \\
\hline Plt $\left(10^{3} / \mathrm{mm}^{3}\right)$ & 124 & $150-400$ \\
\hline $\lg A(g / L)$ & 1.234 & $0.13-1.02$ \\
\hline $\lg G(g / L)$ & 4.318 & $3.49-11.39$ \\
\hline $\lg M(g / L)$ & 0.967 & $0.40-2.29$ \\
\hline $\mathrm{DHR}$ & 180 & $>50$ \\
\hline
\end{tabular}

vaccination, the patient had had full vaccination including BCG, HepB, polio, MMR and DTP without any complications. On the last follow-up at the age of three years, the patient's height and weight were $86 \mathrm{~cm}$ and $9.1 \mathrm{~kg}$, respectively-both below the 3rd percentile corrected for the age. However, she has not had any evidence of immunodeficiency, despite living a normal life without any special precautions to preserve the patient's health.

\section{Discussion and conclusion}

Human cells are exposed to a wide variety of endogenous and exogenous DNA damaging agents. DSBs are considered one of the most severe forms of DNA damage, which could lead to cellular apoptosis or carcinogenesis, if left unrepaired $[4,6,8]$. DSBs are mostly repaired by either homologous recombination or non-homologous end-joining pathway [5]. Animal models evaluating the role of NHEJ pathway in the immune system have highlighted its importance in the immune system [11]. Animal models with defects in NHEJ have $\mathrm{B}$ and $\mathrm{T}$ lymphocyte maturation arrest and even embryonic lethality when accompanied by deficiencies in XRCC4/DNA-Ligase IV complex [12-14]. Given the vital role of repairing DSBs, mutation in any of the NHEJ genes, cause disruption in the immune system development, particularly B cell and $\mathrm{T}$ cell maturation, resulting in 
Table 2 Whole Exome Sequencing detail of coverage and number of reads

\begin{tabular}{|c|c|c|c|}
\hline Type & Value & Type & Value \\
\hline Total Reads & $74,338,832$ & Percent reads on target & $46.45 \%$ \\
\hline Passed filter Unique Reads aligned & $74,253,527$ & Percent Passed filter Unique Reads aligned & $99.89 \%$ \\
\hline Mean Target Coverage & 39.07 & Percent on Target & $46.45 \%$ \\
\hline Percent Duplicate & $22.38 \%$ & Percent duplicate in analysis & $0 \%$ \\
\hline Capture Method & Whole exome sequencing & Run method & NextSeq 500 \\
\hline GC content & $44 \%$ & Sequence length & 125 \\
\hline Nucleotide Covered GTE_1 & $98 \%$ & Nucleotide Covered GTE_5 & $87 \%$ \\
\hline Nucleotide Covered GTE_8 & $79 \%$ & Nucleotide Covered GTE_10 & $75 \%$ \\
\hline Nucleotide Covered GTE_15 & $65 \%$ & Nucleotide Covered GTE_20 & $58 \%$ \\
\hline Nucleotide Covered GTE_30 & $47 \%$ & Nucleotide Covered GTE_40 & $38 \%$ \\
\hline Nucleotide Covered GTE_50 & $31 \%$ & Nucleotide Covered GTE_60 & $24 \%$ \\
\hline Nucleotide Covered GTE_70 & $19 \%$ & Nucleotide Covered GTE_80 & $14 \%$ \\
\hline Nucleotide Covered GTE_90 & $10 \%$ & Nucleotide Covered GTE_100 & $8 \%$ \\
\hline
\end{tabular}

GTE Greater or equal to \#

SCID [6, 8]. SCID presents early during the first few months of life and displays with severe bacterial and opportunistic infections, particularly respiratory infections [9].

In addition, it has been proposed that NHEJ1 has an important role in human cerebral cortex development [15]. Decreased expression of NHEJ1 has been shown to lead to defects in neuronal migration and decreased width of external cortical layers [4]. Furthermore, NHEJ deficiency appears to be a risk factor for the development of malignancy. Defects in NHEJ in P53-deficient mice have been shown to perpetually lead to development of pro-B cell lymphomas [16].

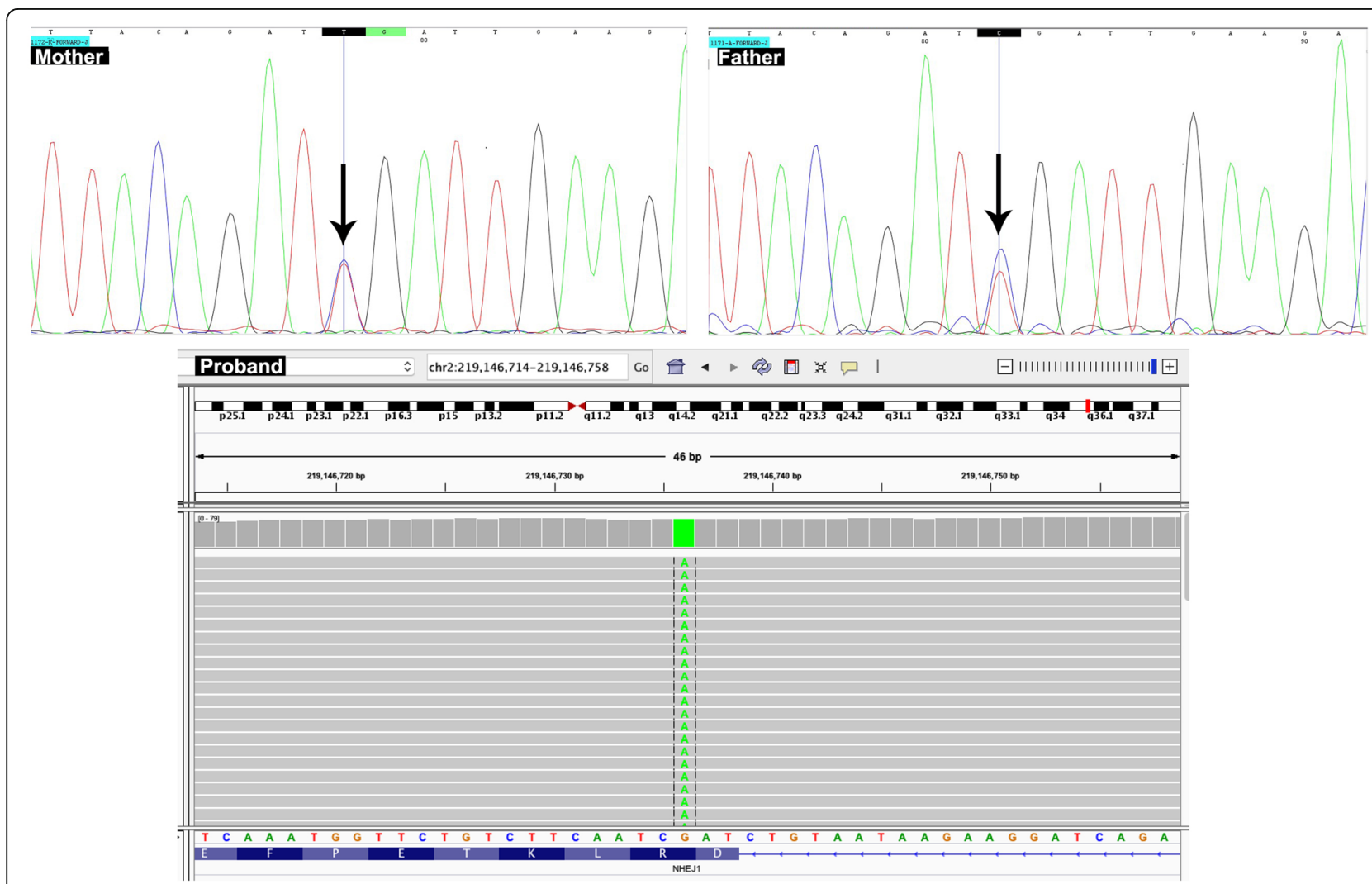

Fig. 1 WES results showing homozygous mutation in NHEJ1 gene in the proband, as visualized using Integrative Genome Viewer (IGV). Sanger sequencing confirms the presence of heterozygous mutation in NHEJI gene in both parents. Arrows indicate the site of the mutation 
During the embryonic period, all cells are in a hypermitotic state. Therefore, mutations in NHEJ1 commonly affect different cell types. Microcephaly, severe growth retardation, dysmorphic facial features and autoimmunity are reported alongside immunodeficiency $[8,17,18]$. To the best of our knowledge, the patient reported here is the first case with a homozygous pathogenic nonsense mutation (CADD score: 37 ) in NHEJ1 gene with a competent immune system. This mutation would lead to the production of a protein lacking about one-third of its C-terminal amino-acid sequence.

We reported a patient with a pathogenic stop-gain mutation in NHEJ1 who presented with AIHA, failure to thrive and microcephaly. However, she had no history of any bacterial or opportunistic infections. No previous history of respiratory infections, chronic diarrhea or any other complains was mentioned by her parents. The patient reported here had no history of prior hospital admission other than the one mentioned due to severe anemia. Buck, et al, reported a patient of Turkish origin with a similar mutation presenting with microcephaly and growth retardation and recurrent bacterial and opportunistic infections who had died at the age of four years due to septic shock [6]. Our findings highlight the importance of other end-joining auxiliary pathways such as polymerase $\theta$-mediated end-joining, also known as a-EJ pathway $[19,20]$. Although, due to the scarce number of individuals with deficiency in NHEJ, the exact role and function of a-EJ pathway is largely unknown, recent studies have emphasized its role in sustaining cell viability and genetic stability in case NHEJ is compromised.

All patients with defects in NHEJ reported to date, have been immunocompromised. Flow-cytometry in these patients demonstrates low $\mathrm{T}$ cell, very low or absent B cell and normal NK cell count. Serum immunoglobulin levels in these patients are generally low for IgG and IgA, and normal or high for IgM $[3,9,18]$. Our Patient had leukopenia with low level of CD19+ cells and very high level of CD56+ cells. In addition, IgA levels were mildly elevated. These findings might be a novel presentation. Further investigations to shed light on how these findings are compatible with immunocompetent phenotype are warranted. FTT and severe growth retardation have reported in all cases of NHEJ mutation [10]. Our patient's weight, length/height and head circumference were below the 3rd percentile at birth and has been below the 3rd percentile on follow-up. Growth chart demonstrated that her growth pattern was not steady, as there were multiple periods of growth arrest. Her development was otherwise normal.

Microcephaly has been widely reported in previous studies, indicating the role of NHEJ gene in cerebral expansion [8]. NHEJ gene mutation leads to apoptotic death of post-mitotic neurons, causing CNS development issues, presenting itself with microcephaly, psychomotor retardation and ataxia [7, 17]. Our patient's head circumference has always been below the 3rd percentile corrected for age. Her neurological development was otherwise normal and no finding in favor of developmental delay was noticed in her history or physical examination.

Live vaccines are absolutely contraindicated in patients with SCID as life-threatening complications could occur [21]. Our patient had complete vaccination record according to the national protocol including BCG, OPV and MMR without any complications except mild axillary lymphadenitis after BCG vaccination, which had resolved without medical intervention. Notably, vaccination against smallpox, chickenpox, influenza, and rotavirus is not part of Iran vaccination program.

Autoimmunity is common in previously reported patients with mutations in NHEJ genes; autoimmune cytopenia in particular is reported to be present in about a quarter of the patients [3, 22, 23]. The patient presented here was initially diagnosed with AIHA, but responded very well to oral prednisolone and required no further interventions.

In conclusion, our report highlights the importance of pathways other than NHEJ in DSB repair. Therefore, clinicians should be aware that pathogenic mutations in NHEJ pathway are not necessarily associated with clinical immunodeficiency.

\section{Abbreviations}

ACLA: Anticardiolipin antibody; AlHA: Autoimmune hemolytic anemia; ANA: Antinuclear antibody; ANCA: Anti-neutrophil cytoplasmic antibody; BCG: Bacillus Calmette-Guérin; CMV: Cytomegalovirus; DSB: Double-strand break; Ds-DNA: Double stranded DNA; DTP: Diphtheria, tetanus and pertussis; FTT: Failure to thrive; MMR: Measles, mumps, and rubella; NHEJ: Nonhomologous end-joining; SCID: Severe combined immunodeficiency; WBC: White blood cell

\section{Acknowledgments}

The authors would like to thank the family members for participating in this study.

\section{Funding}

This study was partly supported by the US NIH NINDS R01NS081208-01A1 awarded to MAF. The study was also partly supported by the NIMAD research grant (940714) awarded to MAF. The funders had no role in the design of the study; in the collection, analyses, or interpretation of data; in the writing of the manuscript, or in the decision to publish the results.

Availability of data and materials

All data are available from the corresponding author on request.

\section{Authors' contributions}

MAF conceived and designed the study, collected, assembled, interpreted NGS data. HE, MRB and ZH clinically evaluated the patient. HE and PH drafted the manuscript. HE, PH and MAF revised the manuscript. DA, MM and MF did the genetic studies. All authors read and approved the final manuscript.

Ethics approval and consent to participate

The Ethics Committee of the Persian BayanGene Research and Training Center approved the study protocol. The parents signed a written informed consent to participate in this study. Written informed consent was obtained from the parents of the patient for the publication of this case report. 


\section{Consent for publication}

The parents of the affected patient have consented to the publication of the case and accompanying clinical and genetics data.

\section{Competing interests}

The authors declare that they have no competing interests.

\section{Publisher's Note}

Springer Nature remains neutral with regard to jurisdictional claims in published maps and institutional affiliations.

\section{Author details}

'Allergy Research Center, Shiraz University of Medical Sciences, Shiraz, Iran. ${ }^{2}$ Department of Allergy and Clinical Immunology, Namazi Hospital, Shiraz University of Medical Sciences, Shiraz, Iran. ${ }^{3}$ Hematology Research Center, Shiraz University of Medical Sciences, Shiraz, Iran. ${ }^{4}$ Persian BayanGene Research and Training Center, Shiraz, Iran. ${ }^{5}$ Student Research Committee, Shiraz University of Medical Sciences, Shiraz, Iran. ${ }^{6}$ Genomic Research Center, Shahid Beheshti University of Medical Sciences, Tehran, Iran. ${ }^{7}$ Comprehensive Medical Genetic Center, Shiraz University of Medical Sciences, Shiraz, Iran. ${ }^{8}$ Department of Medical Genetics, Shiraz University of Medical Sciences, Shiraz, Iran. ${ }^{9}$ Center for Therapeutic Innovation, Department of Psychiatry and Behavioral Sciences, University of Miami Miller School of Medicine, Miami, USA.

\section{Received: 25 December 2018 Accepted: 13 March 2019} Published online: 21 March 2019

\section{References}

1. Lieber MR. The mechanism of double-strand DNA break repair by the nonhomologous DNA end-joining pathway. Annu Rev Biochem. 2010;79: 181-211.

2. Lieber MR, Karanjawala ZE. Ageing, repetitive genomes and DNA damage. Nat Rev Mol Cell Biol. 2004;5(1):69-75.

3. Gellert M. DNA double-strand breaks and hairpins in V(D)J recombination. Semin Immunol. 1994;6(3):125-30.

4. El Waly B, Buhler E, Haddad MR, Villard L. Nhej1 deficiency causes abnormal development of the cerebral cortex. Mol Neurobiol. 2015;52(1):771-82.

5. Sancar A, Lindsey-Boltz LA, Unsal-Kacmaz K, Linn S. Molecular mechanisms of mammalian DNA repair and the DNA damage checkpoints. Annu Rev Biochem. 2004;73:39-85.

6. Buck D, Malivert L, de Chasseval R, Barraud A, Fondaneche MC, Sanal O, Plebani A, Stephan JL, Hufnagel M, le Deist F, et al. Cernunnos, a novel nonhomologous end-joining factor, is mutated in human immunodeficiency with microcephaly. Cell. 2006;124(2):287-99.

7. Revy $P$, Malivert L, de Villartay JP. Cernunnos-XLF, a recently identified nonhomologous end-joining factor required for the development of the immune system. Curr Opin Allergy Clin Immunol. 2006;6(6):416-20.

8. Cagdas D, Ozgur TT, Asal GT, Revy P, De Villartay JP, van der Burg M, Sanal O, Tezcan I. Two SCID cases with Cernunnos-XLF deficiency successfully treated by hematopoietic stem cell transplantation. Pediatr Transplant. 2012; 16(5):E167-71.

9. Sheikh F, Hawwari A, Alhissi S, Al Gazlan S, Al Dhekri H, Rehan Khaliq AM, Borrero E, El-Baik L, Arnaout R, Al-Mousa H, et al. Loss of NHEJ1 protein due to a novel splice site mutation in a family presenting with combined immunodeficiency, microcephaly, and growth retardation and literature review. J Clin Immunol. 2017;37(6):575-81.

10. Turul T, Tezcan I, Sanal O. Cernunnos deficiency: a case report. J Investig Allergol Clin Immunol. 2011;21(4):313-6.

11. de Villartay JP, Fischer A, Durandy A. The mechanisms of immune diversification and their disorders. Nat Rev Immunol. 2003;3(12):962-72.

12. Bryans M, Valenzano MC, Stamato TD. Absence of DNA ligase IV protein in XR-1 cells: evidence for stabilization by XRCC4. Mutat Res. 1999;433(1):53-8.

13. Dudley DD, Chaudhuri J, Bassing CH, Alt FW. Mechanism and control of V(D)J recombination versus class switch recombination: similarities and differences. Adv Immunol. 2005;86:43-112.

14. Revy P, Buck D, le Deist F, de Villartay JP. The repair of DNA damages/ modifications during the maturation of the immune system: lessons from human primary immunodeficiency disorders and animal models. Adv Immunol. 2005;87:237-95.
15. Cantagrel V, Lossi AM, Lisgo S, Missirian C, Borges A, Philip N, Fernandez C, Cardoso C, Figarella-Branger D, Moncla A, et al. Truncation of NHEJ1 in a patient with polymicrogyria. Hum Mutat. 2007;28(4):356-64.

16. Ferguson DO, Alt FW. DNA double strand break repair and chromosomal translocation: lessons from animal models. Oncogene. 2001;20(40):5572-9.

17. Berthet F, Caduff R, Schaad UB, Roten H, Tuchschmid P, Boltshauser E, Seger RA. A syndrome of primary combined immunodeficiency with microcephaly, cerebellar hypoplasia, growth failure and progressive pancytopenia. Eur J Pediatr. 1994;153(5):333-8.

18. Cipe FE, Aydogmus C, Babayigit Hocaoglu A, Kilic M, Kaya GD, Yilmaz Gulec E: Cernunnos/XLF deficiency: a syndromic primary immunodeficiency. Case Rep Pediatr 2014, 2014:614238.

19. Wyatt DW, Feng W, Conlin MP, Yousefzadeh MJ, Roberts SA, Mieczkowski P, Wood RD, Gupta GP, Ramsden DA. Essential roles for polymerase thetamediated end joining in the repair of chromosome breaks. Mol Cell. 2016; 63(4):662-73.

20. Chang HHY, Pannunzio NR, Adachi N, Lieber MR. Non-homologous DNA end joining and alternative pathways to double-strand break repair. Nat Rev Mol Cell Biol. 2017;18(8):495-506.

21. Marciano BE, Huang CY, Joshi G, Rezaei N, Carvalho BC, Allwood Z, Ikinciogullari A, Reda SM, Gennery A, Thon V, et al. BCG vaccination in patients with severe combined immunodeficiency: complications, risks, and vaccination policies. J Allergy Clin Immunol. 2014;133(4):1134-41.

22. Notarangelo LD. Primary immunodeficiencies (PIDs) presenting with cytopenias. Hematology Am Soc Hematol Educ Program. 2009:139-43.

23. S A, M N, Bemanian MH, Shakeri R, Taghvaei B, Ghalebaghi B, Babaie D,

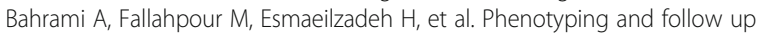
of forty-seven Iranian patients with common variable immunodeficiency. Allergol Immunopathol (Madr). 2016;44(3):226-31.

\section{Ready to submit your research? Choose BMC and benefit from:}

- fast, convenient online submission

- thorough peer review by experienced researchers in your field

- rapid publication on acceptance

- support for research data, including large and complex data types

- gold Open Access which fosters wider collaboration and increased citations

- maximum visibility for your research: over $100 \mathrm{M}$ website views per year

At $\mathrm{BMC}$, research is always in progress.

Learn more biomedcentral.com/submissions 